\title{
Use of taping to maintain centralization in a patient with low back pain with sciatica
}

\author{
Mintken PE* \\ Department of Physical Therapy, University of Colorado School of Medicine, Aurora, USA
}

\section{Introduction}

Low back pain with leg pain is a condition that is commonly encountered in physical therapy [1]. A preliminary goal in treating these patients is to centralize their peripheral symptoms [2], as Skytte et al. [3] reported that patients that did not centralize were 6 times more likely to undergo surgery. The centralization phenomenon is defined as "the progressive retreat of the most distal extent of referred or radicular pain toward or to the lumbar midline [4]. Put simply, the leg pain gets better and "centralizes" to the back. In the Treatment Based Classification of Delitto et al. [5] patients whose symptoms centralize with a movement in one direction and peripheralize with an opposite movement are placed into a specific exercise classification [6].

Centralization has been shown to have value as a prognostic indicator of outcomes [3,7,8]. Wernecke and Hart [7] found that centralization of symptoms led to significantly fewer visits, and Donelson et al. [9] reported excellent and good outcomes in $98 \%$ of "centralizers" symptomatic for 4 weeks or less. Skytte et al. [3] reported that centralizers had less disability and required fewer surgeries at one year. Interpretation of centralization by health care providers is reliable, and consistently associated with a improved prognosis and patient outcomes [3,7-12].

Patients with low back and leg pain often exhibit a "directional preference," $[2,13,14]$, which is defined as "the situation when movements in one direction will improve pain and the limitation of range, whereas movements in the opposite direction cause signs and symptoms to worsen [14]". If a patient has a decrease of pain with extension, for example, the pain is frequently exacerbated by flexion [9,15-19]. Centralization of symptoms commonly occurs when the patient moves in the direction of preference [14]. Long et al. reported that patients who received exercises matching the directional preference had significant reductions in pain and medication use and improved in all other outcomes (disability, degree of recovery, depression, and work interference). Delitto et al. [5] have devised a Treatment Based Classification (TBC) for low back pain. In this classification system, patients that display centralization of symptoms with extension and a peripheralization of symptoms with flexion are placed into the specific exercise extension syndrome classification $[5,6,20]$. The proposed treatment for this classification includes extension exercises and avoidance of flexion [6,13]. Brennan et al. [21] reported in a randomized controlled trial that patients receiving the treatment that matched to their classification in the TBC had better outcomes than patients randomized to an unmatched treatment.

Several studies have examined common factors that exacerbate low back pain. Activities that require lumbar flexion, such as bending forward and sitting, commonly exacerbate low back pain [22-25].
In a study evaluating the daily use and loading of the lumbar spine, Bakker et al. [22] found that flexed postures with activities of daily living (ADL's) were 10 times more common than extended postures. Sitting may induce posterior rotation of the pelvis, reduction of lumbar lordosis, and increases in muscle tension and disc pressure, which may contribute to low back pain [26]. Beattie et al. [27] found that maintaining lordosis in sitting kept the posterior margin of the nucleus pulposa in a more anterior position.

Clinical experience suggests it is not the centralization of symptoms that poses a clinical challenge; rather it is the correction and maintenance of faulty postures. Centralization of symptoms is of no long-lasting benefit to the patient if they repeatedly adopt postures or positions that cause their symptoms to peripheralize (such as sitting through a 2-hour class or bending over the sink to do the dishes). Lumbar rolls are effective $[19,26]$ but they are a passive device, only address spinal position while seated, and rarely change behavior when not present.

In this case, centralization was achieved via specific exercises and manual therapy, but the patient was unable to maintain centralization with his ADL's, specifically with sitting and doing the dishes. The patient could achieve partial reduction independently, but required additional manual therapy to achieve full centralization of his symptoms. Werneke and Hart [7] stated that poor short-term outcomes in pain and disability were noted if symptoms did not centralize by the seventh treatment visit. As we could achieve full centralization in the clinic, we attempted to devise a plan to allow the patient to maintain centralization outside of the clinic. Taping was applied to the patient's back to maintain the centralization as well as the "avoidance of flexion" prescribed by the TBC [5].

Taping has long been used in the successful treatment of musculoskeletal disorders, including the hip, knee, ankle and foot [2840]. Anti-pronation taping has been shown to induce changes in foot posture during standing, walking and running [40]. Taping has been shown to be effective in improving ankle proprioception and preventing ankle sprains [36,39]. While no studies to date have examined the effect of taping on low back pain, it is theoretically possible that tape could provide pain relief and a proprioceptive effect on the low back.

The purpose of this case report is to describe the management

Correspondence to: Paul E Mintken, Department of Physical Therapy, University of Colorado School of Medicine, 13121 E 17th Avenue C-244, Aurora, Colorado 80045, USA, E-mail: Paul.mintken@ucdenver.edu

Received: October 19, 2016; Accepted: November 14, 2016; Published: November 17, 2016 
of a patient with low back and lower extremity pain using extension exercises, manual therapy and taping to facilitate and maintain centralization of symptoms and improve function.

\section{Case description}

\section{Historical examination}

A 19 -year-old male was evaluated following a 1 year history of low back pain. The patient did not recall one specific incident where he injured his back, but related the onset of back pain to skiing one year earlier. The patient's past work history included construction work, and he recalls his back hurting after work occasionally. His back pain had been constant but stable for the previous 11 months, but 4 weeks prior to presenting to physical therapy he had the onset of left leg pain with numbness and tingling down the posterolateral thigh to the medial border of the foot. A Magnetic Resonance Imaging study (MRI) conducted three weeks prior to this encounter revealed an L4-5 left paracentral disc protrusion obscuring the left L5 nerve root.

The patient had 3 sessions of chiropractic treatment several weeks prior to presenting to physical therapy. According to the patient, these treatments included lumbar rotational "adjustments" and offered no improvement. The patient was referred to physical therapy with a diagnosis of "L4-5 paracentral disc protrusion with left sciatica." At the time of the initial visit to physical therapy, the patient complained of radiating pain with bending forward and turning to the left. Sitting was much worse than standing, but he still had pain walking.

\section{Self-report measures}

The patient rated his current pain at a 4 or $5 / 10$ on a Numerical Pain Rating Scale (NPRS) [41]. Stratford and Spadoni [41] reported the intraclass correlation coefficients (ICC) of the NPRS ranged from 0.64-0.86 and Childs et al. [42] reported that the minimum detectable change (MDC) was 2 points. The patient stated the pain had been as high as an $8 / 10$ in the previous 24 hours. He did not relate a specific pattern to the pain, but did say that bending forward and turning to the left increased his leg pain. He also indicated that his left leg felt "weak" when going up and down stairs. His reason for seeking care was to get rid of the leg pain and can return to skiing. The patient was a university student, and his back and leg pain were interfering with sleeping, sitting through class and studying. His recreational activities were also limited. A systems review (assessed via an intake form) revealed that the patient was in good health and had not had any significant past medical problems. His initial Modified Oswestry Disability Index (ODI) score was 46 [43-46]. Davidson and Keating reported that the ICC for the modified ODI ranged between 0.84 and 0.92 and the MDC ranged between 10.5 and 15 [43]. Fritz and Irrgang [46] reported that the ICC for the modified OSW was .90, and the MDC was 6 points.

\section{Physical examination}

The MRI results indicated that the patient had a left paracentral disc protrusion. Studies have shown that a percentage of asymptomatic subjects have disc pathology [47-52]. The TBC avoids specific pathoanatomical diagnoses [5], but it is still clinically useful to attempt to determine if the identified pathology correlates with the patient's presenting symptoms [53]. Since the MRI revealed that the protrusion was obscuring the left L5 nerve root, the lumbar and sacral nerve roots were examined via myotomal testing, deep tendon reflexes, straight leg raise, and sensory testing. As the patient complained of weakness and leg pain, an attempt was made to determine if the identified lesion was contributing to the patient's impairments. It was noted that the patient had a weak extensor hallucis longus (EHL), an absent left Achilles tendon reflex, a positive ipsilateral and contralateral straight leg raise, and decreased sensation to sharp/dull over the L5 dermatome. Vroomen et al. [54] reported the kappas for weakness of the extensor hallucis longus, absent ankle tendon reflex and sensory loss were 0.82 , 0.52 and 0.71 respectively in patients with suspected lumbar nerve root involvement. Hsieh et al. [55] reported intersession reliability of 0.88 for the straight leg raise measured with a standard goniometer. The lumbar spine was examined via active, passive and accessory motions to identify key physical examination findings that would assist in classifying the patient in the TBC $[5,6]$. The goal with the range of motion assessments was to determine if any positions or motions aggravated or relieved the patient's symptoms [2,5,8,9,56-61]. This is useful information as it leads directly to interventions the clinician can use, and identifies possible contributing factors such as poor posture $[2,5,8,9,25,56,60-64]$.

\section{Tests and measures}

Observation of posture revealed decreased lumbar lordosis in standing (evidenced by a flat lumbar spine and a decreased anterior tilt when the orientation of the anterior superior iliac spine was assessed in relation to the posterior superior iliac spine). Vroomen et al. [54] reported a 76\% agreement between examiners when assessing a decrease in lumbar curvature. No lateral shift of the spine was noted. Razmjou et al. [65] reported the kappa for interrater agreement for presence of lateral shift was 0.52 . The patient had poor seated posture with complete loss of lumbar lordosis and a forward head position. Fedorak et al. [66] found that the intrarater reliability of the visual assessment of cervical and lumbar lordosis was fair (kappa=0.50). Sitting for longer than 1 minute caused peripheralization of pain down the posterior thigh to the foot.

Gait analysis revealed decreased stance time on the left leg and decreased hip extension on the left at pushoff. Youdas et al. [67] reported an intertester reliability of $0.88-0.98$ for the temporal aspects of gait in a clinical setting.

Active range of motion into flexion was measured from the tip of the third finger to the floor (fingertip-to-floor) [68], extension was measured qualitatively, lateral flexion was measured as the distance from the end of the third finger to the floor [69] and thoracolumbar rotation was measured with a long arm goniometer with one axis parallel to anterior superior iliac spine (ASIS) and one axis parallel to bilateral acromions (gross thoracolumbar rotation) [70]. Perrett et al. [71] found the fingertip-to-floor test to have excellent validity, reliability (ICC $=0.99$ ), and responsiveness. Lewis et al. [69] found that the fingertip-to-floor measurement had an interrater reliability of 0.96-0.99 for flexion and 0.86-0.96 for lateral flexion. Interrater reliability for thoracolumbar rotation has been reported to be poor to fair with kappa statistics ranging between 0.23 and 0.42 [70]. The patient presented with a gross limitation of flexion that reproduced his leg pain, decreased extension, and limited lateral flexion and rotation left greater than right.

Repeated active motions were performed as described by McKenzie [2], and the results are summarized in Table 1. Repeated movements have been found to be a reliable part of a spinal examination [14,59,65,72]. Fritz et al. [59] reported excellent interrater reliability of judgements of status change (kappa $=0.823$ ) with single, repeated and sustained movements. Razmjou et al. [65] reported that using repeated movements to define the centralization phenomenon and directional preference, agreement was $95 \%(\mathrm{kappa}=0.7 ; \mathrm{P}<0.002)$. The TBC of 
Delitto et al. [5,6] states that a patient whose symptoms centralize with two or more movements in the same direction or centralize with a movement in one direction and peripheralize with an opposite movement should be placed in the specific exercise classification. Fritz et al. [6] reported the overall agreement on treatment based classification decisions was $76 \%$. In this case, repeated flexion peripheralized the symptoms and repeated extension (both in standing and lying) centralized the symptoms. Fritz et al. [59] defined centralization as the condition in which "a neurological sign is improved, or paresthesia or pain is abolished or moves from the periphery toward the lumbar spine."

Passive physiological and passive accessory intervertebral motions (PPIVMs and PAIVMs) were performed as described by Maitland [73]. PPIVMs were assessed in sidelying. The vertebral segments were moved passively through a range of motion to assess any decrease or increase in motion as well as reproduction of symptoms. The author acknowledges that these examination techniques have questionable reliability [74-76], but Fritz et al. [77] found that lumbar spine mobility assessment can be useful in determining patients that may benefit from manipulation or lumbar stabilization. PPIVMS and PAIVMS may, therefore, have validity for clinical management of patients [77,78]. The patient presented with decreased passive lumbar flexion that caused an increase in low back pain. Passive extension was decreased at $\mathrm{L} 4 / 5$ and L5/S1 but was not painful. Sidebending left was decreased, as was left rotation. Left rotation also increased leg and back pain. Right rotation was limited and caused left low back pain but centralized his leg pain. PAIVMs consist of central posterior to anterior motions, unilateral posterior to anterior motions and transverse motions [78]. The patient was found to have decreased central and left unilateral PAIVMs at L4 and L5.

Manual muscle testing was performed as described by Kendall [79]. Weakness was found in the left extensor hallucis longus, the flexor hallucis longus and the hamstrings. The patient also had weak lower abdominals as he was not able to maintain his lumbar spine in neutral with level I lower abdominal exercises as described by Sahrmann [80]. The patient had a difficult time contracting his transversus abdominis and was also not able to fire his multifidus on the left [81-83], even with repeated cueing and tactile feedback [84]. Observation revealed atrophy over the left L4/5 and L5/S1 lumbar multifidus. Paraspinal spasm was noted with palpation from L1-L5 left, and increased tone and pain was noted in the left quadratus lumborum. Boline et al. [85] reported that visual observation of the lumbar spine musculature produced kappa coefficients that ranged from 0.34-0.84 and the kappas for palpation for soft tissue pain ranged from $0.40-0.79$.

Neurological examination revealed $1+$ patellar tendon reflexes bilaterally while the Achilles tendon reflex was $1+$ on the right and absent on the left. As reported earlier, the agreement between two examiners on the absence of the Achilles tendon reflex is $86 \%$ [54]. Straight Leg Raise testing was positive on the left for reproduction of back and leg pain in a dermatomal distribution [54] at 20 degrees and the right at 45 degrees (contralateral straight leg raise). Vroomen et al. [54] reported a kappa for a positive SLR in a dermatomal pattern to be 0.68 and the kappa for crossed SLR was 0.70 . The straight leg raise has been shown to have good sensitivity while the crossed straight leg raise has good specificity [86]. Sensory testing revealed decreased perception of light touch and sharp/dull along the L5 dermatome on the left. This was most prominent on the medial border of the foot. Vroomen et al. [54] reported a kappa of 0.71 for sensory loss in patients with suspected lumbar nerve root involvement.
Identified impairments included pain with lumbar flexion and left rotation as well as left lower extremity weakness and decreased sensation in left leg. The patient had poor posture with decreased lumbar lordosis.

Functional limitations identified in the initial examination included:

1. Inability to sit longer than 10 minutes without severe back and leg pain.

2. Unable to walk longer than 10 minutes without pain.

3. Unable to sleep longer than 2 hours without waking.

4. Unable to perform ADL's (such as brushing teeth and washing dishes) without pain.

\section{Unable to perform recreational activities.}

\section{Evaluation}

The examination and MRI results implicated the L4-5 intervertebral disc as the cause of the patient's back and leg pain. The goal of the examination was to reproduce the asterisk sign (i.e., the patient's back and leg pain) [79], and identify movements and postures that either centralized or peripheralized the patient's pain. In the TBC, if the patient's symptoms centralize with a specific movement (flexion, extension or pelvic translocations), he or she is placed in the specific exercise classification [5,21]. Movements that centralize symptoms are used for treatment, and movements or postures that peripheralize symptoms are avoided $[2,5,13,21,59]$. As stated previously, a primary treatment goal in patients with radiating leg pain is to centralize the patient's pain, as this has been shown in numerous studies to correlate with an improved outcome [1,7-12].

\section{Diagnosis}

Examination findings corroborated the MRI findings which had diagnosed an L4-5 left paracentral disc protrusion obscuring the left L5 nerve root. The patient had peripheralization of his symptoms with flexion and left rotation, decreased DTR's, decreased strength and sensation in the left lower extremity, and a positive straight leg raise and crossed straight leg raise. The straight leg raise test has a sensitivity of $72-97 \%$ and a specificity of $11-66 \%[47,50]$. The crossed straight leg raise has a low sensitivity but a high specificity of (85-100\%) for lower lumbar disk pathology [47,50]. According to Delitto et al's Treatment Based Classification, a physical therapy diagnosis was made that placed the patient in the specific exercise classification with an extension syndrome $[5,6,20]$. The Guide to Physical Therapist Practice would classify the patient as Practice pattern 4F: Impaired joint mobility, motor function, muscle performance, range of motion or reflex integrity secondary to spinal disorders [87].

Numerous Studies have shown that if the intervention can centralize the patient's symptoms, they vastly improve the likelihood of a favorable outcome $[4,7,8,10-12]$. The main goal in treating this patient was to centralize his symptoms (get the pain out of his leg) and progress him to stage II of the TBC as soon as possible. Stage II focuses on addressing impairments and improving function [5]. It is the author's experience that if the pain can be centralized but the patient has a difficult time maintaining centralization with function, taping can facilitate a more rapid transition to stage II of the TBC.

The following goals were set after the initial session: 


\section{Short term goals:}

1. Decrease modified Oswestry score by 10 points in 2 weeks.

2. Improve posture through education and taping to allow the patient to sit 1 hour with pain $\leq 3 / 10$ in 2 weeks.

3. Patient will be able to sleep through the night (not awakened by pain) in 2 weeks.

4. Centralization of patient's leg pain to allow walking 1 mile with no leg pain in 2 weeks.

5. Independent in self correction of peripheral symptoms in 2 weeks.

\section{Long term goals:}

1. Decrease modified Oswestry score by $50 \%$ in 6-8 weeks.

2. Patient will be able to wash dishes and brush his teeth with no pain in 4 weeks.

3. Patient will be able to sit 2 hours painfree during class in 4-6 weeks.

4. Patient will be able to able to walk and perform recreational activities (not including skiing) with pain no greater than $3 / 10$ in 6 weeks.

5. Patient will be independent in a home program for range of motion and strengthening in 6 weeks so that he can manage symptoms independently.

6. Patient will be able to able to return to skiing not limited by back or leg pain in 8-12 weeks.

Criteria for discharge included complete centralization of the patient's symptoms, ability to sit for two hours with no increase in pain, and independence in self-management of symptoms. It was emphasized that self-treatment is infinitely preferable to dependence on therapy. The patient's goal of returning to skiing would probably not be met before we finished formal physical therapy, so it was explained to the patient that his back should be relatively painfree with no functional limitations for a period or 4-6 weeks before he returned to skiing.

\section{Intervention}

The examination revealed that flexion and left rotation caused a peripheralization of the patient's symptoms. Therefore, the intervention strategy would include:

1) Patient education regarding the condition and movements and postures that are to be avoided [5]. $[5,50]$.

2) Active movements to centralize symptoms and restore motion

3) Joint mobilizations to centralize the symptoms, restore range of motion and decrease pain [2,79].

4) Taping of the lumbar spine to assist in the "avoidance of flexion" prescribed by the TBC for patients classified into the extension syndrome.

5) Lumbar stabilization exercises to ensure that the patient had the strength and endurance to maintain functional posture with his activities of daily living and potentially reduce the likelihood of recurrence $[84,88]$.
The intervention began with postural education to avoid postures and movements that peripheralized the pain. This included educating the patient on the concepts of a neutral spine and how to maintain this in sitting and standing. This was followed by biomechanical counseling to teach the patient how to lift and perform ADL's while maintaining a neutral lumbar spine. In a study evaluating the daily use and loading of the lumbar spine, Bakker et al. [22] found that flexed activities were 10 times more common than extended ones. Sitting may induce posterior rotation of the pelvis, reduction of lumbar lordosis, and increases in muscle tension, disc pressure, and pressure on the ischium and coccyx, which may be associated with low back pain [26].

Extension in lying exercises, as described by McKenzie [2], were prescribed based on the examination results and the classification of the patient into the extension syndrome of the TBC. In this case, the patient had increased pain and peripheralization of his symptoms with lumbar flexion, and centralization of symptoms to the buttock with repeated extensions. He was instructed in a home program of extension in lying consisting of 10 repetitions every two hours. If he could not find a place to perform the exercises, he would be instructed to do the extensions in standing. Flexion would be reintroduced once the peripheral symptoms had resolved.

Lumbar rotations and prone central and unilateral $\mathrm{P}-\mathrm{A}$ 's were used to help centralize the symptoms as an adjunct to the extension exercises. Both Maitland [79] and McKenzie [2] describe using rotations to the opposite side of the symptoms to assist in centralization of leg symptoms. The examination revealed that right rotation centralized the patient's symptoms and left rotation peripheralized the symptoms. In this case the patient had left sided back and leg pain, so he was positioned in left sidelying with the painful side down and gentle (grades II and III) right rotation mobilizations [79] quickly resulted in a $50-75 \%$ reduction in the leg pain (Figure 1). This was followed by

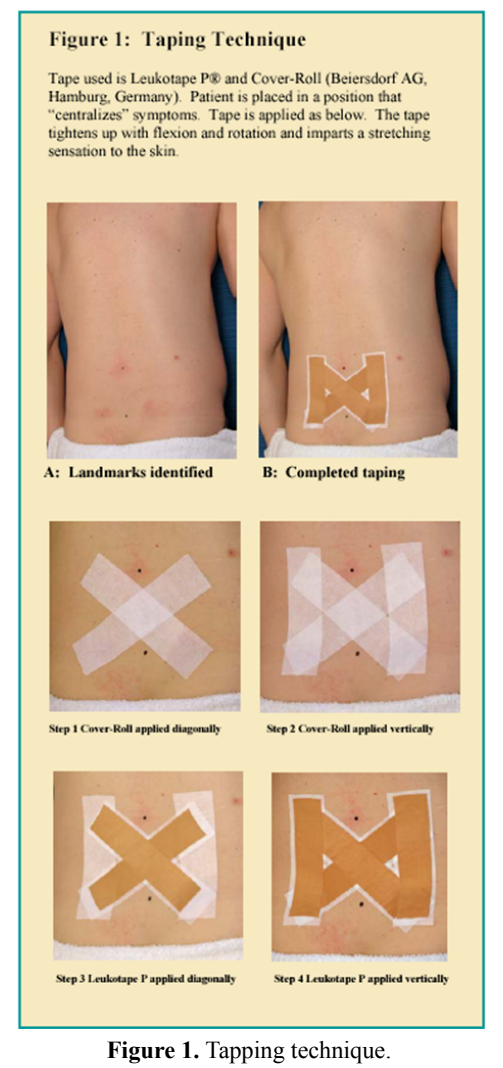

Figure 1. Tapping technique. 
prone passive accessory movements of central and unilateral posterior to anterior mobilizations [79] which resulted in a further improvement in centralization.

Full centralization of symptoms was achieved with the treatment described above, but it was noted the patien would have an immediate peripheralization of his symptoms as soon as he attempted to put his shoes on (despite repeated efforts at biomechanical counseling). He also had rapid peripheralization of his symptoms any time he had to sit longer than 10 minutes. One of the main treatment recommendations for the Treatment Based Classification (TBC) specific exercise: extension syndrome is avoidance of flexion [20]. The tape was used to assist the patient in avoiding flexion and possibly improve proprioception, specifically in the presence of a long standing hypolordotic posture [89-91]. Taping the lumbar spine was introduced at the end of the treatment before the patient got up from the table, and allowed the patient to maintain centralization of his symptoms. The taping technique consists of applying strips of Cover Roll along the paraspinals from the first lumbar vertebra to the first sacral vertebra in a vertical fashion followed by two diagonal strips connecting the top of one vertical strip to the bottom of the other vertical strip (Figure 2). Leukotape is then applied over the four strips of Cover Roll to provide extra support. The Cover Roll/Leukotape combination is highly resistant to stretch, and is frequently used in the treatment of patellofemoral pain $[29,32,35,37,92]$. Patients report that the tape helps them identify movements and postures that may exacerbate or peripheralize their pain, and this helps them to immediately problem solve and generate alternative postures that decrease the stress on their low back. Patients often only need to be taped once or twice before they learn what movements and postures may be harmful. Patients are generally allowed to leave the tape on for up to a week, as long as they do not have any type of skin reaction to the tape [92]. The tape must be removed slowly and the adhesive residue removed with nail polish remover. The patient must inspect the skin for any signs of allergic reaction or skin breakdown. The patient described in this case report had very poor posture, and it was difficult for him to maintain centralization of symptoms without feedback or cues. This led to frequent episodes of peripheralizing pain with daily activities.

Lumbar stabilization exercises were initiated once pain was under control and the patient had progressed to stage II of the TBC. Hodges et al. $[82,83,93]$ has demonstrated that the lumbar multifidus and transverses abdominus fire to stabilize the lumbar spine prior to initiating an extremity movement in people without low back pain. Hodges has also found that the firing of these muscles, and, hence, the dynamic stabilization of the lumbar spine is frequently delayed in patients with low back pain $[82,83,93]$. Studies have shown that there can be atrophy in the lumbar multifidus that does not improve

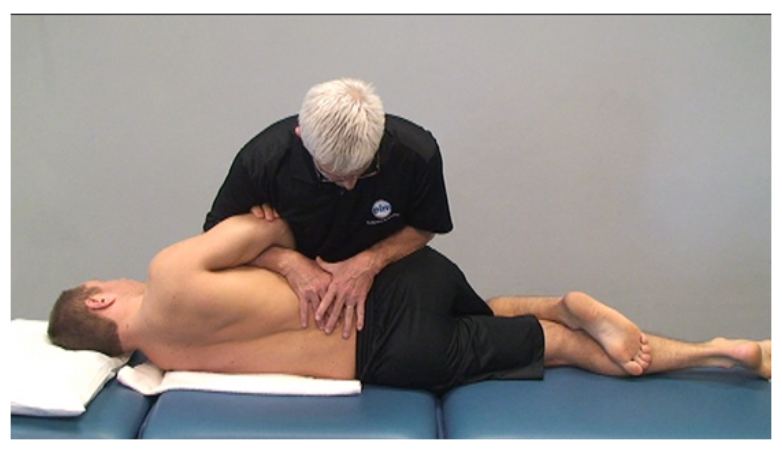

Figure 2. Lumbar rotations. following an acute bout of back pain [94-96].

It is important to note that while patients in the specific exercise classification are extensively counseled regarding correct body mechanics, it is imperative not to generate a fear of movement [97]. It was thoroughly explained to this patient that flexion and rotation may hinder his recovery at this stage of healing, but that these motions are necessary components of normal movement. It was explained that these motions must be minimized until the symptoms are under control, then the motions can be reintroduced (Actual interventions by session are described in Table 2).

\section{Outcomes}

The physical impairments measured during the initial examination and at discharge are listed in Table 3. At the end of the five weeks of treatment, the patient had centralization of his leg pain, full lumbar range of motion, improved straight leg raise, Achilles tendon reflex present bilaterally, and improved motor function. The patient could sit for two hours with no back pain and no leg pain. He demonstrated improved posture with sitting and functional tasks such as bending over a sink. The patient's pain improved from an $8 / 10$ at the initial visit to a $2-3 / 10$ at the discharge visit. His final modified ODI score was a 16. The patient reported improvement in sleeping, personal care, school and work activities, ability to engage in recreational/sport activities, and general function (Table 4 for patient reported outcome measures). The patient's stress level went up, but this could be due to the fact that the discharge visit occurred prior to final exam week.

\section{Discussion}

Numerous interventions have been reported for low back pain [98]. Frequently, the etiology is unknown which makes determining the optimal intervention difficult. Identifying subgroups of patients and tailoring the treatment to a specific treatment based classification has resulted in improved outcomes in multiple studies [5,21,99-102]. It has been the author's experience that many times there are gray areas in the classification approach. The patient described in this case clearly fit the specific exercise classification, but also benefited from lumbar mobilizations as well as taping to avoid postures and positions that peripheralized his symptoms. While this treatment was successful, it is possible that other interventions may have been as efficacious or that the patient may have improved over time without intervention.

The specific exercise classification in the TBC calls for exercises and postures that centralize symptoms while avoiding postures and movements that peripheralize symptoms $[5,6,20]$. The patient in this case had difficulty maintaining good posture, and, hence, centralization of his symptoms. Manual therapy and taping were introduced in an attempt to achieve and maintain centralization of symptoms. The manual therapy techniques were used to facilitate a rapid centralization of symptoms and the taping theoretically provided support and proprioceptive feedback to help the patient avoid symptom producing motions and postures. Spinal stabilization exercises and movements into flexion were introduced when the patient's pain had improved and his symptoms had centralized and become stable [84].

The main new treatment outlined in this case report concerns taping of the lumbar spine. It is described as an adjunct to the examination and treatment approaches pioneered by Maitland [79] and McKenzie [2] as well as the treatment based classification of Delitto et al. [5] It is hypothesized that the tape provided a mechanical restraint to lumbar flexion as well as proprioceptive feedback. While 
Table 1. McKenzie repeated movements.

\begin{tabular}{|c|c|c|}
\hline Session & Assessment & Treatment \\
\hline $\begin{array}{l}\text { Session } 1, \\
\text { Day } 1\end{array}$ & $\begin{array}{ll}- & \text { Subjective: See history in text } \\
\text { - } & \text { NPRS: } 8 / 10 \\
\text { - } & \text { Modified Oswestry score: } 46 \\
& \text { Objective: See examination in text }\end{array}$ & $\begin{array}{ll}- & \text { Education regarding condition } \\
- & \text { Postural counseling (avoidance of flexion) } \\
- & \text { Extension in lying (EIL) to be done for } 10 \text { reps every } 2 \text { hours }\end{array}$ \\
\hline $\begin{array}{l}\text { Session 2, } \\
\text { Day } 6\end{array}$ & $\begin{array}{l}\text { - Subjective: Felt great until he had to sit through } 2 \text { hour class, then leg pain } \\
\text { returned with washing dishes } 2 \text { days prior that caused numbness left foot for } \\
\text { last } 2 \text { days } \\
\text { NPRS: 6-7/10 } \\
\text { Objective: Kyphotic lumbar posture, flexion caused peripheralization of } \\
\text { symptoms, SLR + left at } 20 \text { degrees }\end{array}$ & $\begin{array}{l}\text { - } \\
\text { Left sidelying Right rotation mobs } \mathrm{f} / \mathrm{b} \text { prone left unilateral P-A's at } \\
\text { - } \\
\text { Prone EIL } 10 \text { reps } \\
\text { Taping technique L1-S1, told to take off at end of day and assess skin } \\
\text { integrity } \\
\text { Postural education }\end{array}$ \\
\hline $\begin{array}{l}\text { Session } 3, \\
\text { Day } 8\end{array}$ & $\begin{array}{l}\text { - Subjective: Leg pain much better, no return of numbness. Tape "helped" posture, } \\
\text { able to sit through } 2 \text { hour class with no leg pain and minimal back pain. Once tape } \\
\text { was removed, did have increased leg pain with brushing teeth, resolved when he } \\
\text { corrected posture. } \\
\text { NPRS: } 5 / 10 \\
\text { Objective: Achilles reflex present at } 1+\text { (was absent), lumbar extension nearly } \\
\text { full, SLR + left at } 35 \text { degrees, skin showed no signs of reaction to tape. }\end{array}$ & $\begin{array}{l}\text { - } \\
\text { - } \quad \text { Bepeat of session } 2 \\
\text { was given } \\
\text { Taping was used again at the end of treatment, and the patient was told } \\
\text { he could keep tape on for 2-3 days }\end{array}$ \\
\hline $\begin{array}{l}\text { Session } 4, \\
\text { Day } 14\end{array}$ & $\begin{array}{l}\text { - Subjective: Had been feeling much better, in "minor" MVA that caused leg pain } \\
\text { to return } \\
\text { - } \\
\text { - } \\
\text { ObRS: } 4 / 10 \\
\text { symptive: Marked limitation of flexion and left rotation with peripheralization of } \\
\end{array}$ & $\begin{array}{l}\text { - } \\
\text { Left sidelying Right rotation mobs } \mathrm{f} / \mathrm{b} \text { prone left unilateral P-A's at } \\
\text { - } \quad \text { Prone EIL } 2 \times 10 \text { reps } \\
\text { Inititation of independent activation and tonic hold of transversus } \\
\text { abdominis and lumbar multifidus } 10 \times 10 \text { seconds }\end{array}$ \\
\hline $\begin{array}{l}\text { Session } 5 \\
\text { Day } 16\end{array}$ & $\begin{array}{l}\text { - } \\
\text { - } \\
\text { subjective: Leg pain and back pain better, some intermittent numbness in leg } \\
\text { NPRS: } 3-4 / 10 \\
\text { Objective: Flexion to } 16 \text { " from floor, full extension and rotation, SLR } 35 \text { degrees, } \\
\text { contralateral SLR } 47 \text { degrees, mild restriction left unilateral P-A at L4/5 }\end{array}$ & 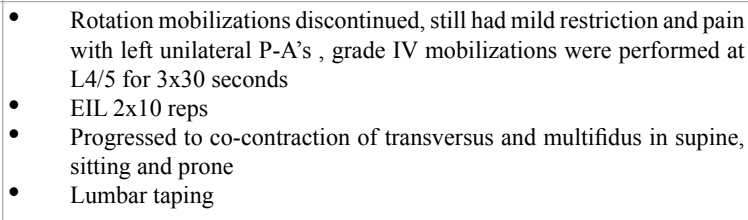 \\
\hline $\begin{array}{l}\text { Session } 6 \\
\text { Day } 23\end{array}$ & $\begin{array}{l}\text { - Subjective: Not much back and leg pain, mild tingling in foot with driving, able to } \\
\text { centralize. Able to sit through class and perform ADL's with no back pain } \\
\text { NPRS: } 0 / 10 \text { at rest, } 3 / 10 \text { at worst } \\
\text { - } \quad \text { Objective: Flexion to } 12 \text { " from floor limited by hamstrings, full symmetrical } \\
\text { sidebending, Achiles DTR } 1+\text {, SLR to } 30 \text { degrees, contralateral SLR to } 55 \text { degrees }\end{array}$ & $\begin{array}{l}\text { - Progressed to dynamic activation of the transversus and multifidus by } \\
\text { superimposing leg movements in supine, sidelying and prone. } \\
\text { Flexion in lying introduced to be followed by immediately by } \\
\text { extension in lying } 10 \text { reps } 3 \mathrm{x} / \text { day } \\
\text { - Tape was discontinued }\end{array}$ \\
\hline $\begin{array}{l}\text { Session } 7 \\
\text { Day } 37\end{array}$ & $\begin{array}{l}\text { - } \quad \text { Subjective: No pain currently in leg or back } \\
\text { - } \quad \text { NPRS: 0/10 at rest, 2-3/10 if he performs ADL's incorrectly } \\
\text { - } \quad \text { Oodified Oswestry score: } 16 \\
\text { Objective: Full lumbar ROM, FHL, EHL and hamstrings on the left } 5 / 5 \text {, SLR to } \\
40 \text { degrees, positive slump test on the left. }\end{array}$ & $\begin{array}{l}\text { - Progressed transversus and multifidus exercises to functional } \\
\text { activities (contraction while standing, lifting a box, etc.) } \\
\text { Initiated seated nerve glides (neutral spine with knee extension } \mathrm{f} / \mathrm{b} \\
\text { dorsiflexion) } 3 \times 10 \text { reps to onset of discomfort } \\
\text { - Initiated supine hamstring stretches } 30 \text { seconds } 2 \mathrm{x} / \mathrm{day}\end{array}$ \\
\hline $\begin{array}{l}\text { Phone follow up } \\
\text { day } 67\end{array}$ & - Doing well, no recurrence of back pain. & Reassurance, encouraged to continue home program \\
\hline $\begin{array}{l}\text { Phone follow up } 12 \\
\text { months }\end{array}$ & $\begin{array}{l}\text { - No recurrence in } 12 \text { months, did have minor bouts of low back pain (2-3/10), but } \\
\text { these never limited his function. }\end{array}$ & Reassurance, encouraged to continue home program \\
\hline
\end{tabular}

Table 2. Actual interventions.

\begin{tabular}{|l|l|}
\hline \multicolumn{1}{|c|}{ Motion tested } & \\
\hline $\begin{array}{l}\text { Side Glide in standing to the right } \\
\text { (shifting the trunk sideward and over the pelvis in the direction indicated) }\end{array}$ & Decreased pain left lower back and leg. \\
\hline Repeated Side Glide in standing to the right & Decreased pain left lower back and leg. \\
\hline Side Glide in standing to the left & Increased left low back pain and pain in posterior thigh. \\
\hline Repeated Side Glide in standing to the left & Increased pain in back and leg down to foot \\
\hline Repeated Extension in Standing & Increased left low back pain, pain centralized out of leg into back. \\
\hline $\begin{array}{l}\text { Flexion in Lying } \\
\text { (bringing the knees to the sides of the chest in supine) }\end{array}$ & Increased low back and posterior thigh pain. \\
\hline Repeated Flexion in Lying & Increased low back and posterior thigh pain. \\
\hline $\begin{array}{l}\text { Extension in Lying (pressups in prone, like pushups only the pelvis stays in contact with the } \\
\text { supporting surface) }\end{array}$ & Pain at L4/5, mild buttock pain. \\
\hline Repeated Extension in Lying & $\begin{array}{l}\text { Pain moved entirely into back, no leg or buttock pain. Back pain diminished with each } \\
\text { repetition until 10 reps. }\end{array}$ \\
\hline
\end{tabular}

there have been no controlled studies evaluating the effect of tape on low back pain, taping has long been used in the treatment of musculoskeletal disorders [28,29,31-40,92,103]. Taping has been shown to be effective in improving ankle and knee proprioception and preventing ankle sprains [36,38,39,104-108]. Simoneau et al. [107] concluded that strips of athletic tape applied across the ankle joint of healthy individuals improved ankle joint position perception in nonweightbearing. Refshauge et al. [109] did not find that ankle taping enhanced proprioception in the sagittal plane. Allison et al. [110] reported that ankle taping did not alter neurophysiological responses 
Table 3. Tests and measures utilized for re-examination.

\begin{tabular}{|c|c|c|}
\hline Test/Measure & Initial Visit & Discharge Visit \\
\hline Posture & Kyphotic lumbar spine in standing and sitting & $\begin{array}{l}\text { Able to maintain a neutral spine with sitting and } \\
\text { function. }\end{array}$ \\
\hline Flexion Active Range of Motion & To 24" from floor with peripheralization of pain to left foot & $\begin{array}{l}\text { Full range of motion with only mild pain at end range } \\
\text { flexion. }\end{array}$ \\
\hline Extension Active Range of Motion & Limited $50 \%$ with centralization & Full and painfree \\
\hline $\begin{array}{l}\text { Passive Accessory Intervertebral Motions } \\
\text { (PAIVMs) }\end{array}$ & $\begin{array}{l}\text { Back and leg pain with grade III central and unilateral posterior-anterior forces at L4 } \\
\text { and L5 (deemed hypomobile by therapist) }\end{array}$ & Painfree except mild pain with left unilateral P-A at L4/5 \\
\hline DTR & Achilles reflex absent Left & 1+ Bilaterally \\
\hline $\begin{array}{l}\text { SLR } \\
\text { (left leg) }\end{array}$ & Positive at 20 degrees for left low back and left leg pain below the knee & Positive at 40 degrees with mild low back pain \\
\hline $\begin{array}{l}\text { Crossed SLR } \\
\text { (right leg) }\end{array}$ & Positive at 45 degrees for left low back pain and left buttock pain & Limited by hamstring stretch at 55 degrees \\
\hline Sensation & Impaired L5 dermatome & Normal \\
\hline Manual Muscle Testing & Left extensor hallucis longus $4 / 5$, flexor hallucis longus and hamstrings graded $4+/ 5$ & Full Strength \\
\hline Sitting & 1 minute & $\begin{array}{l}\text { Able to sit for two hours with minimal back pain, no } \\
\text { leg pain }\end{array}$ \\
\hline ADL's & Unable to do dishes and brush teeth & No problems with ADL's \\
\hline Recreation & Unable to participate & Able to ski \\
\hline Oswestry Score & 46 & 16 \\
\hline
\end{tabular}

Table 4. Outcome measures (standard clinic outcome measure).

\begin{tabular}{|c|c|c|c|}
\hline Question & Scale Utilized & $\begin{array}{l}\text { Response at } \\
\text { Initial Visit }\end{array}$ & $\begin{array}{l}\text { Response at } \\
\text { Discharge Visit }\end{array}$ \\
\hline Do you have difficulty sleeping? & $\begin{array}{l}\text { No difficulty }=5 \\
\text { My sleep is completely disturbed }=1\end{array}$ & 2 & 5 \\
\hline $\begin{array}{l}\text { Do you have difficulty with personal care (dressing, } \\
\text { washing, grooming, etc.)? }\end{array}$ & $\begin{array}{l}\text { No difficulty=5 } \\
\text { I am completely dependent on others for my personal care=1 }\end{array}$ & 3 & 5 \\
\hline Do you have difficulty with school or work activities? & $\begin{array}{l}\text { No difficulty }=5 \\
\text { I am unable to perform any school or work activities }=1\end{array}$ & 3 & 5 \\
\hline $\begin{array}{l}\text { Are you able to engage in recreational/sport activities as } \\
\text { you did prior to your injury? }\end{array}$ & $\begin{array}{l}\text { Able to fully participate in pre-injury recreational } / \text { sport activities }=5 \\
\text { Unable to fully participate in pre-injury recreational } / \text { sport activities }=1\end{array}$ & 1 & 5 \\
\hline Please rate your current level of overall functioning. & $\begin{array}{l}\text { I am functioning at my pre-injury level=5 } \\
\text { I am at the worst level of functioning since my injury=1 }\end{array}$ & 2 & 4 \\
\hline Please rate your worst pain in the last 48 hours. & $\begin{array}{l}\text { Worst pain imaginable }=10 \\
\text { No pain }=0\end{array}$ & 8 & $2-3$ \\
\hline Please rate the amount of stress currently in your life. & $\begin{array}{l}\text { Worst stress imaginable }=10 \\
\text { No stress }=0\end{array}$ & 3 & 5 \\
\hline $\begin{array}{l}\text { Please rate the amount of improvement in your condition } \\
\text { since the beginning of your physical therapy treatment. } \\
(* \text { Assessed only at discharge) }\end{array}$ & $\begin{array}{l}\text { Complete recovery }=5 \\
\text { No improvement }=1\end{array}$ & $*$ & 4 \\
\hline $\begin{array}{l}\text { Please rate your adherence with the home program given } \\
\text { to you by your physical therapist. } \\
(* \text { Assessed only at discharge) }\end{array}$ & $\begin{array}{l}\text { I performed my home program regularly as instructed }=5 \\
\text { I never performed my home program }=1\end{array}$ & * & 4 \\
\hline
\end{tabular}

to sudden inversion in normal subjects. Zanella et al. [111] reported that scapular taping had no effect on joint repositioning during active shoulder flexion or abduction.

The low back pain episode described in this case had started one year prior to the initiation of treatment. While it is unknown whether the treatments had an effect on the pathology, the improvement of the patient's symptoms, physical impairments and functional limitations coincided with the initiation of classification based physical therapy treatments. The patient was contacted 12 months after discontinuing therapy, and he reported no recurrence up to that point. It has been reported that most episodes of low back pain typically resolve within 6 weeks, and that only $5 \%$ of individuals have symptoms lasting longer than 3 months [112], however, a recent study by Tubach et al. [113] found that of 622 patients with sciatica, 53\% reported continued pain four years after the onset of pain, and of the patients that had recovered from sciatica, $61 \%$ continued to have low back pain 2 years later. This data would seem to imply that recovery from low back pain and sciatica is not as common as was once thought.

Further research is needed to determine the effects of the treatments outlined above. To the author's knowledge, there have been no studies examining the effects of taping on low back pain. Does the tape actually improve lumbar spine proprioception? Does it provide any kind of structural support? Does it actually improve a patient's resting posture? Does it change muscle recruitment or firing patterns? Future controlled trials need to be conducted to establish the efficacy of the above treatments alone and in combination.

\section{References}

1. Long A, Donelson R, Fung T (2004) Does it matter which exercise? A randomized control trial of exercise for low back pain. Spine (Phila Pa 1976) 29: 2593-2602. [crossref]

2. McKenzie R (2003) The Lumbar Spine: Mechanical Diagnosis and Therapy. Waikanae, New Zealand: Spinal Publications.

3. Skytte L, May S, Petersen P (2005) Centralization: its prognostic value in patients with referred symptoms and sciatica. Spine (Phila Pa 1976) 30: E293-E299. [crossref]

4. Donelson R, Aprill C, Medcalf R, Grant W (1997) A prospective study of centralization of lumbar and referred pain. A predictor of symptomatic discs and anular competence. Spine (Phila Pa 1976) 22: 1115-1122. [crossref]

5. Delitto A, Erhard RE, Bowling RW (1995) A treatment-based classification approach to 
low back syndrome: identifying and staging patients for conservative treatment. Phys Ther 75: 470-485.

6. Fritz JM, Brennan GP, Clifford SN, Hunter SJ, Thackeray A (2006) An examination of the reliability of a classification algorithm for subgrouping patients with low back pain. Spine (Phila Pa 1976) 31: 77-82. [crossref]

7. Werneke M, Hart DL (2001) Centralization phenomenon as a prognostic factor for chronic low back pain and disability. Spine (Phila Pa 1976) 26: 758-764. [crossref]

8. Werneke M, Hart DL, Cook D (1999) A descriptive study of the centralization phenomenon. A prospective analysis. Spine (Phila Pa 1976) 24: 676-683. [crossref]

9. Donelson R, Silva G, Murphy K (1990) Centralization phenomenon. Its usefulness in evaluating and treating referred pain. Spine (Phila Pa 1976) 15: 211-213. [crossref]

10. Karas R, McIntosh G, Hall H, Wilson L, Melles T (1997) The relationship between nonorganic signs and centralization of symptoms in the prediction of return to work for patients with low back pain. Phys Ther 77: 354-360. [crossref]

11. Long AL (1995) The centralization phenomenon. Its usefulness as a predictor or outcome in conservative treatment of chronic law back pain (a pilot study). Spine (Phila Pa 1976) 20: 2513-2520. [crossref]

12. Sufka A, Hauger B, Trenary M, Bishop B, Hagen A, et al. (1998) Centralization of low back pain and perceived functional outcome. J Orthop Sports Phys Ther 27: 205-212. [crossref]

13. Fritz JM, George S (2000) The use of a classification approach to identify subgroups of patients with acute low back pain. Interrater reliability and short-term treatment outcomes. Spine 25: 106-114.

14. Kilpikoski S, Airaksinen O, Kankaanpää M, Leminen P, Videman T, et al. (2002) Interexaminer reliability of low back pain assessment using the McKenzie method. Spine (Phila Pa 1976) 27: E207-E214. [crossref]

15. Alexander AH, Jones AM, Rosenbaum DH (1992) Nonoperative management of herniated nucleus pulposus: patient selection by the extension sign. Long-term followup. Orthopaedic Review 21: 181-188.

16. Kopp JR, Alexander AH, Turocy RH, Levrini MG, Lichtman DM (1986) The use of lumbar extension in the evaluation and treatment of patients with acute herniated nucleus pulposus. A preliminary report. Clin Orthop Relat Res 1986: 211-218. [crossref]

17. Snook SH, Webster BS, McGorry RW, Fogleman MT, McCann KB (1998) The reduction of chronic nonspecific low back pain through the control of early morning lumbar flexion. A randomized controlled trial. Spine (Phila Pa 1976) 23: 2601-2607. [crossref]

18. Spratt KF, Weinstein JN, Lehmann TR, Woody J, Sayre H (1993) Efficacy of flexion and extension treatments incorporating braces for low-back pain patients with retrodisplacement, spondylolisthesis, or normal sagittal translation. Spine (Phila Pa 1976) 18: 1839-1849. [crossref]

19. Williams MM, Hawley JA, McKenzie RA, van Wijmen PM (1991) A comparison of the effects of two sitting postures on back and referred pain. Spine (Phila Pa 1976) 16: 1185-1191. [crossref]

20. George SZ, Delitto A (2005) Clinical examination variables discriminate among treatment-based classification groups: a study of construct validity in patients with acute low back pain. Phys Ther 85: 306-314. [crossref]

21. Brennan GP, Fritz JM, Hunter SJ, Thackeray A, Delitto A, et al. (2006) Identifying subgroups of patients with acute/subacute "nonspecific" low back pain: results of a randomized clinical trial. Spine (Phila Pa 1976) 31: 623-631. [crossref]

22. Bakker EP, Koning HJ, Verhagen AP, Koes BW (2003) Interobserver reliability of the 24-hour schedule in patients with low back pain: a questionnaire measuring the daily use and loading of the spine. J Manipulative Physiol Ther 26: 226-232. [crossref]

23. Biering-Sorensen F (1983) A prospective study of low back pain in a general population. II. Location, character, aggravating and relieving factors. Scand J Rehabil Med 15: 81-88.

24. Boissonnault W, Fabio RP (1996) Pain profile of patients with low back pain referred to physical therapy. J Orthop Sports Phys Ther 24: 180-191. [crossref]

25. Stankovic R, Johnell O (1990) Conservative treatment of acute low-back pain. A prospective randomized trial: McKenzie method of treatment versus patient education in "mini back school". Spine 15: 120-123.

26. Makhsous M, Lin F, Hendrix RW, Hepler M, Zhang LQ (2003) Sitting with adjustable ischial and back supports: biomechanical changes. Spine (Phila Pa 1976) 28: 11131121. [crossref]
27. Beattie PF, Brooks WM, Rothstein JM, Sibbitt WL Jr, Robergs RA, et al. (1994) Effect of lordosis on the position of the nucleus pulposus in supine subjects. A study using magnetic resonance imaging. Spine (Phila Pa 1976) 19: 2096-2102. [crossref]

28. Bockrath K, Wooden C, Worrell T, Ingersoll CD, Farr J (1993) Effects of patella taping on patella position and perceived pain. Med Sci Sports Exerc 25: 989-992. [crossref]

29. Cowan SM, Bennell KL, Hodges PW (2002) Therapeutic patellar taping changes the timing of vasti muscle activation in people with patellofemoral pain syndrome. Clin J Sport Med 12: 339-347.

30. Cowan SM, Hodges PW, Crossley KM, Bennell KL (2006) Patellar taping does not change the amplitude of electromyographic activity of the vasti in a stair stepping task. Br J Sports Med 40: 30-34. [crossref]

31. Crossley K, Cowan SM, Bennell KL, McConnell J (2000) Patellar taping: is clinical success supported by scientific evidence? Man Ther 5: 142-150. [crossref]

32. Gilleard W, McConnell J, Parsons D (1998) The effect of patellar taping on the onset of vastus medialis obliquus and vastus lateralis muscle activity in persons with patellofemoral pain. Physical Therapy 78: 25-32.

33. Kilbreath SL, Perkins S, Crosbie J, McConnell J (2006) Gluteal taping improves hip extension during stance phase of walking following stroke. Aust J Physiother 52: 5356. [crossref]

34. Pfeiffer RP, DeBeliso M, Shea KG, Kelley L, Irmischer B, et al. (2004) Kinematic MRI assessment of McConnell taping before and after exercise. Am J Sports Med 32: 621-628. [crossref]

35. Powers CM, Landel R, Sosnick T, Kirby J, Mengel K, et al. (1997) The effects of patellar taping on stride characteristics and joint motion in subjects with patellofemoral pain. J Orthop Sports Phys Ther 26: 286-291. [crossref]

36. Robbins S, Waked E, Rappel R (1995) Ankle taping improves proprioception before and after exercise in young men. Br J Sports Med 29: 242-247.

37. Salsich GB, Brechter JH, Farwell D, Powers CM (2002) The effects of patellar taping on knee kinetics, kinematics, and vastus lateralis muscle activity during stair ambulation in individuals with patellofemoral pain. J Orthop Sports Phys Ther 32: 3-10. [crossref]

38. Verhagen EA, van der Beek AJ, van Mechelen W (2001) The effect of tape, braces and shoes on ankle range of motion. Sports Med 31: 667-677. [crossref]

39. Verhagen EA, van Mechelen W, de Vente W (2000) The effect of preventive measures on the incidence of ankle sprains. Clin J Sport Med 10: 291-296. [crossref]

40. Vicenzino B, Franettovich M, McPoil T, T Russell, G Skardoon, et al. (2005) Initial effects of anti-pronation tape on the medial longitudinal arch during walking and running. Br J Sports Med 39: 939-943. [crossref]

41. Stratford PW, Spadoni G (2001) The reliability, consistency, and clinical application of a numeric pain rating scale. Physiotherapy Canada 53: 88-91.

42. Childs JD, Piva SR, Fritz JM (2005) Responsiveness of the numeric pain rating scale in patients with low back pain. Spine (Phila Pa 1976) 30: 1331-1334. [crossref]

43. Davidson M, Keating JL (2002) A comparison of five low back disability questionnaires: reliability and responsiveness. Physical Therapy 82: 8-24.

44. Fairbank JC, Couper J, Davies JB, O’Brien JP (1980) The Oswestry low back pain disability questionnaire. Physiotherapy 66: 271-273. [crossref]

45. Fisher K, Johnston M (1997) Validation of the Oswestry Low Back Pain Disability Questionnaire, its sensitivity as a measure of change following treatment and its relationship with other aspects of the chronic pain experience. Physiotherapy Theory and Practice 13: 67-80.

46. Fritz JM, Irrgang JJ (2001) A comparison of a modified Oswestry Low Back Pain Disability Questionnaire and the Quebec Back Pain Disability Scale. Phys Ther 81: 776-788. [crossref]

47. Andersson GB, Deyo RA (1996) History and physical examination in patients with herniated lumbar discs. Spine (Phila Pa 1976) 21: 10S-18S. [crossref]

48. Boden SD, Davis DO, Dina TS, Patronas NJ, Wiesel SW (1990) Abnormal magneticresonance scans of the lumbar spine in asymptomatic subjects. A prospective investigation. J Bone Joint Surg Am 72: 403-8. [crossref]

49. Borenstein DG, O'Mara JW Jr, Boden SD, Lauerman WC, Jacobson A, et al. (2001) The value of magnetic resonance imaging of the lumbar spine to predict low-back pain in asymptomatic subjects: a seven-year follow-up study. J Bone Joint Surg Am 83-A: 1306-1311. [crossref]

50. Deyo RA, Rainville J, Kent DL (1992) What can the history and physical examination 
tell us about low back pain? JAMA 268: 760-765. [crossref]

51. Jensen MC, Brant-Zawadzki MN, Obuchowski N, Modic MT, Malkasian D, et al (1994) Magnetic resonance imaging of the lumbar spine in people without back pain. $N$ Engl J Med 331: 69-73. [crossref]

52. Wiesel SW, Tsourmas N, Feffer HL, Citrin CM, Patronas N (1984) A study of computerassisted tomography. I. The incidence of positive CAT scans in an asymptomatic group of patients. Spine (Phila Pa 1976) 9: 549-551. [crossref]

53. Strayer A (2005) Lumbar spine: common pathology and interventions. $J$ Neurosci Nurs 37: 181-193. [crossref]

54. Vroomen PC, de Krom MC, Knottnerus JA (2000) Consistency of history taking and physical examination in patients with suspected lumbar nerve root involvement. Spine 25: 91-96.

55. Hsieh CY, Walker JM, Gillis K (1983) Straight-leg-raising test. Comparison of three instruments. Phys Ther 63: 1429-1433. [crossref]

56. Delitto A, Cibulka MT, Erhard RE, Bowling RW, Tenhula JA (1993) Evidence for use of an extension-mobilization category in acute low back syndrome: a prescriptive validation pilot study. Phys Ther 73: 216-222. [crossref]

57. Donelson R (1990) The McKenzie approach to evaluating and treating low back pain. Orthop Rev 19: 681-686. [crossref]

58. Donelson R, Grant W, Kamps C, Medcalf R (1991) Pain response to sagittal endrange spinal motion. A prospective, randomized, multicentered trial. Spine (Phila Pa 1976) 16: S206-S212. [crossref]

59. Fritz JM, Delitto A, Vignovic M, Busse RG (2000) Interrater reliability of judgments of the centralization phenomenon and status change during movement testing in patients with low back pain. Arch Phys Med Rehabil 81: 57-61. [crossref]

60. Werneke MW, Hart DL (2005) Centralization: association between repeated end-range pain responses and behavioral signs in patients with acute non-specific low back pain. $J$ Rehabil Med 37: 286-290. [crossref]

61. Wetzel FT, Donelson R (2003) The role of repeated end-range/pain response assessment in the management of symptomatic lumbar discs. Spine Journal 3: 146-154.

62. Donelson R, McKenzie R (1992) Effects of spinal flexion and extension exercises on low-back pain and spinal mobility in chronic mechanical low-back pain patients. Spine (Phila Pa 1976) 17: 1267-1268. [crossref]

63. Erhard RE, Delitto A, Cibulka MT (1994) Relative effectiveness of an extension program and a combined program of manipulation and flexion and extension exercises in patients with acute low back syndrome. Physical Therapy 74: 1093-1100.

64. Nwuga G, Nwuga V (1985) Relative therapeutic efficacy of the Williams and McKenzie protocols in back pain management. Physiotherapy Practice 1: 99-105.

65. Razmjou H, Kramer JF, Yamada R (2000) Intertester reliability of the McKenzie evaluation in assessing patients with mechanical low-back pain. J Orthop Sports Phys Ther 30: 368-383.

66. Fedorak C, Ashworth N, Marshall J, Paull H (2003) Reliability of the visual assessment of cervical and lumbar lordosis: how good are we? Spine 28: 1857-1859. [crossref]

67. Youdas JW, Atwood AL, Harris-Love MO, Stiller TL, Egan KS, et al. (2000) Measurements of temporal aspects of gait obtained with a multimemory stopwatch in persons with gait impairments. J Orthop Sports Phys Ther 30: 279-286. [crossref]

68. Gauvin MG, Riddle DL, Rothstein JM (1990) Reliability of clinical measurements of forward bending using the modified fingertip-to-floor method. Phys Ther 70: 443-447. [crossref]

69. Lewis JS, Hewitt JS, Billington L, Cole S, Byng J, et al. (2005) A randomized clinical trial comparing two physiotherapy interventions for chronic low back pain. Spine (Phila Pa 1976) 30: 711-721. [crossref]

70. Nitschke JE, Nattrass CL, Disler PB, Chou MJ, Ooi KT (1999) Reliability of the American Medical Association guides' model for measuring spinal range of motion. Its implication for whole-person impairment rating. Spine 24: 262-268. [crossref]

71. Perret C, Poiraudeau S, Fermanian J, Colau MM, Benhamou MA, et al. (2001) Validity, reliability, and responsiveness of the fingertip-to-floor test. Arch Phys Med Rehabil 82: 1566-1570. [crossref]

72. Kilby J, Stigant M, Roberts A (1990) The reliability of back pain assessment by physiotherapists, using a "McKenzie algorithm". Physiotherapy 76: 579-583.

73. Binkley J, Stratford PW, Gill C (1995) Interrater reliability of lumbar accessory motion mobility testing. Phys Ther 75: 786-792. [crossref]
74. Maher C, Adams R (1994) Reliability of pain and stiffness assessments in clinical manual lumbar spine examination... including commentary by Shields RK with author response. Physical Therapy 74: 801-811.

75. Phillips DR, Twomey LT (1996) A comparison of manual diagnosis with a diagnosis established by a uni-level lumbar spinal block procedure. Manual Therapy 1: 82-87.

76. Fritz JM, Whitman JM, Childs JD (2005) Lumbar spine segmental mobility assessment: an examination of validity for determining intervention strategies in patients with low back pain. Arch Phys Med Rehabil 86: 1745-1752.

77. Maher CG, Latimer J, Adams R (1998) An investigation of the reliability and validity of posteroanterior spinal stiffiness judgments made using a reference-based protocol. Physical Therapy 78: 829-837.

78. Kendall FP, McCreary EK, Provance PG (1993) Muscles: Testing \& Function. (4th ed.) Baltimore: Williams \& Wilkins.

79. Maitland G, Hengeveld E, Banks K (2001) Maitland's Vertebral Manipulation. (6th ed.) Oxford: Butterworth-Heinemann.

80. Sahrmann S (2001) Diagnosis and Treatment of Movement Impairment Syndromes St. Louis: Mosby.

81. Hodges P, Richardson C, Jull G (1996) Evaluation of the relationship between laboratory and clinical tests of transversus abdominis function. Physiotherapy Research International 1: 30-40.

82. Hodges PW, Richardson CA (1999) Altered trunk muscle recruitment in people with low back pain with upper limb movement at different speeds. Arch Phys Med Rehabil 80: 1005-1012. [crossref]

83. Hodges PW, Richardson CA (1996) Inefficient muscular stabilization of the lumbar spine associated with low back pain: a motor control evaluation of transversus abdominis. Spine 21: 2640-2650.

84. Richardson CA, Hodges PW, Hides JA (2004) Therapeutic Exercise for Spinal Segmental Stabilization in Low Back Pain. Edinburgh, London, New York, Philadelphia, Sydney, Toronto: Churchill Livingstone.

85. Boline PD, Haas M, Meyer JJ, Kassak K, Nelson C, et al. (1993) Interexaminer reliability of eight evaluative dimensions of lumbar segmental abnormality: Part II. $J$ Manipulative Physiol Ther 16: 363-374. [crossref]

86. Jarvik JG, Deyo RA (2002) Diagnostic evaluation of low back pain with emphasis on imaging. Ann Intern Med 137: 586-597. [crossref]

87. American Physical Therapy Association GtPTP, 2001.

88. Hides JA, Jull GA, Richardson CA (2001) Long-term effects of specific stabilizing exercises for first-episode low back pain. Spine (Phila Pa 1976) 26: E243-E248. [crossref]

89. Adams MA, Hutton WC (1983) The effect of posture on the fluid content of lumbar intervertebral discs. Spine (Phila Pa 1976) 8: 665-671. [crossref]

90. Adams MA, Hutton WC (1985) Gradual disc prolapse. Spine (Phila Pa 1976) 10: 524 531. [crossref]

91. Dolan P, Adams MA, Hutton WC (1988) Commonly adopted postures and their effect on the lumbar spine. Spine (Phila Pa 1976) 13: 197-201. [crossref]

92. Crossley K, Bennell K, Green S, Cowan S, McConnell J (2002) Physical therapy for patellofemoral pain: a randomized, double-blinded, placebo-controlled trial. Am J Sports Med 30: 857-865.

93. Hodges PW, Richardson CA (1997) Contraction of the abdominal muscles associated with movement of the lower limb... including commentary by Hasan $\mathrm{Z}$ with author response. Physical Therapy 77: 132-144. [crossref]

94. Hides JA, Richardson CA, Jull GA (1995) Magnetic resonance imaging and ultrasonography of the lumbar multifidus muscle. Comparison of two different modalities. Spine 20: 54-58.

95. Hides JA, Richardson CA, Jull GA (1996) Multifidus muscle recovery is not automatic after resolution of acute, first-episode low back pain. Spine (Phila Pa 1976) 21: 2763 2769. [crossref]

96. Hides JA, Stokes MJ, Saide M, Jull GA, Cooper DH (1994) Evidence of lumbar multifidus muscle wasting ipsilateral to symptoms in patients with acute/subacute low back pain. Spine (Phila Pa 1976) 19: 165-172. [crossref]

97. Fritz JM, George SZ (2002) Identifying psychosocial variables in patients with acute work-related low back pain: the importance of fear-avoidance beliefs. Phys Ther 82 973-983. [crossref] 
98. van Tulder MW, Koes BW, Bouter LM (1997) Conservative treatment of acute and chronic nonspecific low back pain. A systematic review of randomized controlled trials of the most common interventions. Spine 22: 2128-2156.

99. Childs JD, Fritz JM, Flynn TW, Irrgang JJ, Johnson KK, et al. (2004) A clinical prediction rule to identify patients with low back pain most likely to benefit from spinal manipulation: a validation study. Ann Intern Med 141: 920-928. [crossref]

100. Flynn T, Fritz J, Whitman J, Wainner R, Magel J, et al. (2002) A clinical prediction rule for classifying patients with low back pain who demonstrate short-term improvement with spinal manipulation. Spine (Phila Pa 1976) 27: 2835-2843. [crossref]

101. Fritz JM (1998) Use of a classification approach to the treatment of 3 patients with low back syndrome. Phys Ther 78: 766-777. [crossref]

102. Fritz JM, Delitto A, Erhard RE (2003) Comparison of classification-based physical therapy with therapy based on clinical practice guidelines for patients with acute low back pain: a randomized clinical trial. Spine 28: 1363-1371.

103. Crossley K, Bennell K, Green S, McConnell J (2001) A systematic review of physical interventions for patellofemoral pain syndrome. Clin J Sport Med 11: 103-110. [crossref]

104. Callaghan MJ, Selfe J, Bagley PJ, Oldham JA (2002) The Effects of Patellar Taping on Knee Joint Proprioception. J Athl Train 37: 19-24. [crossref]

105. Heit EJ, Lephart SM, Rozzi SL (1996) The effect of ankle bracing and taping on joint position sense in the stable ankle. $J$ Sport Rehabil 5: 206-213.

106. Kaminski TW, Gerlach TM (2001) The effect of tape and neoprene ankle supports on ankle joint position sense. Phys Ther Sport 2: 132-140.

107. Simoneau GG, Degner RM, Kramper CA, Kittleson KH (1997) Changes in ankle joint proprioception resulting from strips of athletic tape applied over the skin. $J$ Athl Train 32: 141-147. [crossref]

08. You SH, Granata KP, Bunker LK (2004) Effects of circumferential ankle pressure on ankle proprioception, stiffness, and postural stability: a preliminary investigation. $J$ Orthop Sports Phys Ther 34: 449-460.

109. Refshauge KM, Kilbreath SL, Raymond J (2000) The effect of recurrent ankle inversion sprain and taping on proprioception at the ankle. Med Sci Sports Exerc 32: 10-15. [crossref]

110. Allison GT, Hopper D, Martin L, Tillberg N, Woodhouse D (1999) The influence of rigid taping on peroneal latency in normal ankles. Aust J Physiother 45: 195-201. [crossref]

111. Zanella PW, Willey SM, Seibel SL, Hughes CJ (2001) The effect of scapular taping on shoulder joint repositioning. J Sport Rehab 10: 113-123.

112. Frymoyer JW (1988) Back pain and sciatica. N Engl J Med 318: 291-300. [crossref]

113. Tubach F, Beauté J, Leclerc A (2004) Natural history and prognostic indicators of sciatica. J Clin Epidemiol 57: 174-179. [crossref]

Copyright: @2016 Mintken PE. This is an open-access article distributed under the terms of the Creative Commons Attribution License, which permits unrestricted use, distribution, and reproduction in any medium, provided the original author and source are credited. 